\title{
Reevaluation of the California Corpus Delicti Rule: A Response to the Invitation of Proposition 8
}

\author{
Maria Lisa Crisera $\uparrow$
}

Courts throughout the United States have long recognized the importance of protecting criminal defendants from convictions based on unreliable extrajudicial confessions. This Comment demonstrates that the corpus delicti rule, as applied in California, does not effectively serve that goal. The author argues that the rule itself is inefficient and subject to abuse by defense counsel, and that California courts have interpreted the rule in such a way as to destroy its protective value. The author then analyzes the corpus delicti rule in light of section 28(d), the "Right to Truth-inEvidence" provision added to the California Constitution in 1982 by voter initiative. The author concludes that section 28(d) abrogated the corpus delicti rule and that the California Legislature should seize upon this opportunity to clarify the state policy regarding extrajudicial confession evidence by adopting a flexible confession corroboration rule similar to that of the federal courts.

Until the nineteenth century, Enghish courts considered the criminal defendant's extrajudicial confession sufficient evidence to convict. ${ }^{1}$ This policy, not surprisingly, resulted in some notorious cases in which a homicide victim suddenly reappeared after a conviction had been obtained solely on the basis of a confession. ${ }^{2}$ The English courts, therefore, began to reconsider the confession's evidentiary value and to require some corroboration of the confession. The corroboration rule was never very strong in English or Irish courts, where today it seems to apply only in lomicide cases, if at all. ${ }^{3}$

In the United States, the common law corroboration rule evolved

$\dagger$ A.B., 1987, Harvard College; J.D. candidate 1991, Boalt Hall School of Law, University of California, Berkeley. The author wishes to thank the members of the California Law Review for their help in preparing this Comment. Special thanks to Professor Preble Stolz for the guidance and editorial advice that made the publication process virtually painless.

1. Note, Proof of the Corpus Delicti Aliunde: The Defendant's Confession, 103 U. PA. L. REV. 638,638 (1955).

2. United States v. Gresham, 585 F.2d 103, 106 (5th Cir. 1978); see, e.g., Perry's Case, in 14 A Complete Collection of State Trials 1312-17 (T. Howell ed. 1812) ("victim" reappeared after his alleged murderer had been convicted and executed solely on the basis of a confession).

3. 7 J. Wigmore, Evidence $\$ 2070$, at 510 (Chadbourn rev. ed. 1978). 
into two distinct forms. Soine courts interpreted the rule to require independent evidence to establisli the rehability or trustworthiness of the defendant's out-of-court stateinent. The majority of courts took a more restrictive view, ${ }^{4}$ requiring proof of the "corpus delicti"- the fact of injury or the "body" of the crime-independent of the defendant's confession. ${ }^{5}$ In contrast to the English approach, American courts extended the rule to nearly all crimes. ${ }^{6}$ They recognized three elements within the corpus delicti: (1) the occurrence of injury; (2) a criminal cause of the injury; and (3) the identity of the perpetrator. ${ }^{7}$ However, they interpreted the rule as requiring independent proof of only the first two elements. ${ }^{8}$

As travel and communications improved, the original justification for the corroboration rule in its various forms weakened. A "victim" was less likely to reappear alive after his alleged murderer had been convicted on the basis of only an extrajudicial confession. Rather than doing away with the rule, ${ }^{9}$ lowever, American courts simply offered new justifications for it. Most of these justifications focused on the need to encourage good law enforcement practices and to protect criminal defendants froin bad practices, ${ }^{10}$ but the courts also offered the rule as a

4. Id. § 2071 , at 516 .

5. 2 C. Wright, Federal Practice and Procedure $§ 414$, at 516 (2d ed. 1982). Although the corpus delicti rule arose in the context of homicide cases, the term does not refer to the corpse of the alleged crime victim. "There seems to be an impression on the part of some that the term 'corpus delicti' means 'the body of the deceased,' which it is insisted must be found and produced before a conviction of murder can be had. The rightful meaning of this term is 'the body, the substance, the essential elements of the crime.'" People v. Watters, 202 Cal. 154, 156-57, 259 P. 442, 443 (1927) (citing People v. Simonsen, 107 Cal. 345, 347, 40 P. 440, 440 (1895)).

6. Note, supra note 1, at 641 . This expansion of the corpus delicti rule has led in recent years to the criticism that the rule is unworkable in cases involving detailed statutory crimes, State v. Parker, 315 N.C. 222, 232, 337 S.E.2d 487, 493 (1985), or crimes entailing no injury. Id.; United States v. Sluunk, 881 F.2d 917,920 (10th Cir. 1989).

7. $7 \mathrm{~J}$. WIGMORE, supra note $3, \S 2072$, at 524 .

8. Id. $\S 2072$, at 524-26.

9. A few critics probably would have been dehighted to abolish any form of corroboration requirement. Professor Wigmore, for example, had little use for the corroboration rule. He felt that the danger of false confessious was slight and that, at any rate, counsel or the court could just as easily warn the jury of the dangers against which the rule was supposed to protect. Moreover, lie feared that the rule could be abused to obstruct justice. $7 \mathrm{~J}$. WIGMORE, supra note $3, \S 2070$, at 510 . Judge Learned Hand also doubted whether justice required sucli a rule. Daeclie v. Urited States, 250 F. 566, 571 (2d Cir. 1918) (questioning the corroboration rule yet applying it because it was so well established in the federal courts at the time).

10. The United States Supreme Court argued that the rule encouraged "sound" law enforcement by forcing police to go beyond the defendant's confession in investigating a crime. Smith v. United States, 348 U.S. 147, 153 (1954). The Court also saw the rule as a protection against police brutality and coerced confessions, $c f$. id. (confessions resulting from police pressure may be unreliable), and against excessive prosecutorial zeal. Opper v. United States, 348 U.S. 84, 89-90 (1954). 
necessary means of protecting potential criminal defendants from themselves. ${ }^{11}$

Despite the wealth of modern justifications for the corroboration rule, a number of courts and commentators have suggested that the corpus dehicti form of the rule has outhived any useful purpose it might once have had. ${ }^{12}$ First, they argue that the corpus dehicti rule was illsuited from the outset to its stated purpose of protecting the defendant from conviction on the basis of a false confession. ${ }^{13}$ Second, they maintain that recent developments in criminal law and procedure have rendered the rule both impractical and unnecessary. ${ }^{14}$ In response to these criticisms, a growing number of courts now favor the more flexible corroboration rule over the strict corpus dehicti rule. ${ }^{15}$ Califormia courts,

11. Courts were concerned that sensational and widely publicized crimes would attract nientally imbalanced yet innocent confessors. United States v. Gresham, 585 F.2d 103, 106 (5th Cir. 1978); see also Forte v. United States, 94 F.2d 236, 238 (D.C. Cir. 1937) (courts concerned by prospect of false confessions, "coerced or psyeliopathic"). Furthermore, the Supreme Court itself acknowledged that even technically uncoerced statements may be unreliable if the defendant makes them under the stress of a police investigation. Smith, 348 U.S. at 153; Opper, 348 U.S. at 89-90.

12. See, e.g., United States v. Shunk, 881 F.2d 917, 919 (10th Cir. 1989); United States v. Kerley, 838 F.2d 932, 939-40 (7th Cir. 1988). For a more detailed discussion of both justifications for and nodern criticisms of the corpus delicti rule, see Comment, California's Corpus Delicti Rule: The Case for Review and Clarification, 20 UCLA L. REv. 1055, 1087-92 (1973) (authored by J. Terry Scliwartz).

13. See State v. Tillman, 152 Conn. 15, 20, 202 A.2d 494, 496 (1964) (strict application of corpus delicti rule "creates complications and difficulties" at trial which "tend to produce unjnst results because of the greater hazard that mistakes will be made by the court or jury"); State v. Lucas, 30 N.J. 37, 57, 152 A.2d 50, 60 (1959) ("There seems to be little difference in kind between convicting the innocent where no crime has been committed and convicting the innocent where a crime has been committed, but not by the accused."); Comment, supra note 12, at 1090 (corpus delicti rule offers no protection to an insane defendant who pleads guilty since no evidence against him is ever presented in court); see also Shunk, 881 F.2d at 920 (since the corpus delicti concept is irrelevant to crimes-such as possession of a firearm by a convicted felon-that entail no tangible injury, it offers criminal defendants little protection in prosecutions for sucli crimes); Comment, supra note 12, at 1089 (if it is proper for law enforcement officers to bear the full burden of establishinig the elements of a crime in order to ensure the protection of criminal defendants from conviction on the basis of false confessions, the logical conclnsion is to exclude all confessions, not just extrajudicial ones).

14. State v. Parker, 315 N.C. 222, 232, 337 S.E.2d 487, 493 (1985) (quoting MCCoRMICK ON EvidENCE \$145, at 371 (E. Cleary 3d ed. 1984)) (defining the corpns delicti has beconie increasingly burdensoine and complex because modern statutes define offenses in greater detail than their predecessors did). Moreover, other legal safeguards now exist to protect against conviction on the basis of an unreliable confession. See, e.g., State v. Yoshida, 44 Haw. 352, 358, 354 P.2d 986, 990 (1960) (constitutional requirements that voluntariness of confession be shown and that defendant's guilt be proven beyond a reasonable doubt afford the defendant considerable protection); Comment, supra note 12, at 1089 (Miranda v. Arizona, 384 U.S. 436 (1966), "limit[s] opportunity for over-zealous law enforcement").

15. Opper v. United States, 348 U.S. 84, 92-93 (1954) (Court recognized conflict among circuits and found corroborated confessions admissible); Yoshida, 44 Haw. at 357, 354 P.2d at 990 (adopted corroboration rule in case of first impression); Parker, 315 N.C. at 236, 337 S.E.2d at 495 (abandoned corpus delicti rule in favor of corroboration rule); State v. George, 109 N.H. 531, 533, 257 A.2d 19, 20-21 (1969) (apphed corroboration rule); State v. Lucas, 30 N.J. 37, 51-57, 152 A.2d 
however, have stubbornly adhered, in form if not in substance, to the strict version of the rnle.

The 1965 adoption of the state evidence code offered California courts an opportunity to do away with the corpus dehcti rule: Section 351 of the code inakes all relevant evidence admissible, except as provided by statute. ${ }^{16}$ However, the only court to address the issue concluded that this "firmly established and fundamental rnle of the criminal law of years' standing was [not] overruled by any vague and indecisive provision in the Evidence Code."17 The court in People v. Starr ${ }^{18}$ based its holding solely on the fact that several California courts had continued to apply the corpus dehicti rnle after the adoption of the new evidence code. ${ }^{19}$ Since all those courts apphed the rnle inechanically, without considerimg whether it had survived section $351,{ }^{20}$ the Starr court's rehance on thein was misplaced. Despite the weakness of the Starr court's reasoning and the widespread criticisin of the corpus dehcti rule, the Califorma Supreine Court never took up the issue of section 351's impact on the rnle.

In June of 1982, Califorma voters passed Proposition 8, offering the courts another opportunity to reexamine the corpus dehicti rule. Proposition 8 added section 28 to article I of the Califorma Constitution. This amendinent includes a "Right to Truth-in-Evidence" provision declaring, in essence, that "relevant evidence shall not be excluded in any criminal proceeding" except where subsequently provided by statute. ${ }^{21}$

Although no Califorma court has yet considered section 28(d)'s imipact on the corpus delicti rule, the "Right to Truth-in-Evidence" provision secins to present another opportunity to do away with a bad evidentiary rule. ${ }^{22}$ Part I of this Comment argues that the corpus dehicti

50, 57-60 (1959) (claimed that New Jersey has always followed more flexible form of rule); State v. Paris, 76 N.M. 291, 294-95, 414 P.2d 512, 514-15 (1966) (applied corroboration rule in case of first impression).

16. CAL. Evid. Code $\S 351$ (West 1960).

17. People v. Starr, 11 Cal. App. 3d 574, 583, 89 Cal. Rptr. 906,912 (1970).

18. 11 Cal. App. 3d 574, 89 Cal. Rptr. 906 (1970).

19. Id. at 581-83, $89 \mathrm{Cal}$. Rptr. at 911-12.

20. Id. at 583, 89 Cal. Rptr. at 912 (Gustafson, J., dissenting); Comment, supra note 12, at 1080.

21. Section 28 (d) provides:

Right to Truth-in-Evidence. Except as provided by statute hereafter enacted by a twothirds vote of the membership in each house of the Legislature, relevant evidence shall not be excluded in any criminal proceeding, including pretrial and post conviction unotions and hearings, or in any trial or hearing of a juvenile for a criminal offense, whether heard in juvenile or adult court. Nothing in this section slaall affect any existing statutory rule of evidence relating to privilege or hearsay, or Evidence Code Sections 352, 782 or 1103. Nothing in this section shall affect any existing statutory or constitutional right of the press.

CAL. ConsT. art I, § 28(d).

22. It is significant that in Kaplan v. Superior Court, 6 Cal. 3d 150, 491 P.2d 1, 98 Cal. Rptr. 
rule offers the criminal accused hittle, if any, real protection in California because the courts have read the rule so loosely. Part II inaintains that the continued existence of even this essentially hollow rule imposes a burden on prosecutors, who must still go through the motions of establishing the corpus delicti of a crime, and simultaneously offers defense counsel a potentially dangerous tool. Part III considers the potential impact of Proposition 8 on the California corpus delicti rule. Finally, Part IV proposes that the legislature enact an evidence code provision clearly and expressly abandoning the rule in favor of the inore flexible corroboration rule.

I

\section{Hollowness of the Modern California Corpus Delicti Rule}

California, like tle majority of American jurisdictions, adopted the corpus delicti version of the corroboration rule. California judges have fornulated tlie corpus delicti rule as an evidentiary rule under whiclı a defendant's extrajudicial confession is admissible only if the prosecution has establislied (1) the fact of injury and (2) the criminal source of injury, ${ }^{23}$ by proof independent of the confession. ${ }^{24}$

Although the California courts liave never directly addressed the post-Proposition 8 validity of the state corpus delicti rule, since 1982 the courts lave interpreted the rule im ways that liave undercut its purpose of protecting the accused from conviction on the basis of an unreliable confession. The courts persist in citing the corpus delicti rule and purport to follow it, but their decisions have considerably undermined the rule's force. The courts appear to liave lost faith in tlie spirit or purpose of the rule and seem intent on finding ways to get around its letter in order to admit extrajudicial confessions and admissions into evidence.

While the California courts continue to require independent proof of the mjury and criminality eleinents of the corpus delicti, they require only a slight or prima facie sliowing of those eleinents. ${ }^{25}$ Moreover, they maintain that purely circumstantial evidence suffices to establish the

649 (1971), appeal dismissed, 407 U.S. 917 (1972), the California Supreme Court relied on Starr to conclude that the vicarious exclusionary rule survived Evidence Code section 351. Kaplan, $6 \mathrm{Cal}$. 3d at 161, 491 P.2d at 8, $98 \mathrm{Cal}$. Rptr. at 656. In In re Lance W., $37 \mathrm{Cal}$. 3d 873, 694 P.2d 744, 210 Cal. Rptr. 631 (1985), lowever, the court leeld that Proposition 8 abrogated that same rule. Id. at 886-87, 694 P.2d at 752, 210 Cal. Rptr. at 639. The Lance $W$. decision may indicate an increased willingness on the part of the court to do away with evidentiary rules it deems unnecessary or undesirable.

23. 1 B. Witkin \& N. Esstein, California Criminal Law $\S 136$ (2d ed. 1988).

24. Id. § 137; People v. Alcala, $36 \mathrm{Cal}$. 3d 604, 624, 685 P.2d 1126, 1136, 205 Cal. Rptr. 775, 785 (1984).

25. 1 B. WITKIN \& N. ExSTEIN, supra note 23, § 140; Alcala, $36 \mathrm{Cal}$. 3d at 624-25, 685 P.2d at 1136, $205 \mathrm{Cal}$. Rptr. at 785. 
corpus delicti of a crime. ${ }^{26}$

The existence of sufficient independent proof of the corpus delicti is a question of preliminary fact. If the corpus delicti has not been established, the defendant's extrajudicial confession is inadmissible-not because it is irrelevant but because it is deeined "unreliable." The corpus delicti question should therefore be left to the judge alone, in keeping witl California Evidence Code section $405 .^{27}$ In practice, however, California courts instruct the jury on the corpus dehicti rule. ${ }^{28}$ Apparently, after the judge has heard the independent evidence out of court and lias found a prima facie sliowing of the corpus delicti, he resubmits the issue to the jury. The jury must find sufficient independent proof of the corpus delicti before it can consider the defendant's confession and reach the ultimate issue of guilt. ${ }^{29}$

Penmitting the jury to consider the corpus dehcti question clearly undercuts the protective purpose of the corpus delicti rule. The comphcated corpus dehicti jury instruction is likely to confuse the jurors. Most jurors, failing to understand the mstruction, will then probably disregard it and consider the defendant's extrajudicial confession-whether or not there is sufficient proof of the corpus delicti. ${ }^{30}$ Moreover, as Justice Gustafson noted in his dissent in People v. Starr, ${ }^{31}$ even if the jurors do understand the instruction, it requires them " "to perforn the impossible task of erasing the hearsay statement [i.e., the defendant's extrajudicial confession] from their minds if they conclude that the condition of admissibility has not been met." "32

26. 1 B. WITKIn \& N. EPSTEIN, supra note 23, $\S 141 ;$ Alcala, 36 Cal. $3 d$ at 624,685 P.2d at 1136, 205 Cal. Rptr. at 785.

27. "Section 405 deals with evidentiary rules designed to withhold evidence from the jury because it is too unreliable to be evaluated properly or because public policy requires its exclusion." CAL. EVID. CODE $\S 405$ comment at 277 (West 1966). Section 405 requires, for example, that the judge make the final determination as to whether a confession is voluntary. Id. at 280-82.

28. California Jury Instructions, Criminal No. 2.72 (A. Levin 5th ed. 1988).

29. Id.; see also Comment, Corroborating Confessions: An Empirical Analysis of Legal Safeguards Against False Confessions. 1984 WIS. L. REV. 1121, 1140-41 (authored by Corey John Ayling); Comment, California Evidence Code 1228: A Constitutional Analysis, 17 PAC. L.J. 917, 923 (1986) (authored by Patrick Michael Broderick) [hereinafter Comment, Evidence Code 1228].

30. Equally dangerous, however, is the possibility that the complicated corpus delicti jury instruction will cause a windfall to the defendant. The confused jurors might misapply the instruction and exclude the defendant's confession from their deliberations when there is sufficient independent proof of the corpus delicti. Thus, their confusion could ultimately result in the acquittal of a guilty defendant.

31. 11 Cal. App. 3d 574, 89 Cal. Rptr. 906 (1970).

32. Id. at 586, 89 Cal. Rptr. at 914 (Gustafson, J., dissenting) (quoting 6 CAL. L. REvisioN COMM'N REP. 30 (1964)). Similar fears that juries' inability to follow limiting instructions would prejudice defendants led both the Umited States Supreme Court and the California Supreme Court to prohibit the use at joint trials of a codefendant's extrajudicial confession implicating the defendant in instances where the codefendant is not available to testify or be cross-examined. See Bruton v. Umited States, 391 U.S. 123, 137 (1968) ("[I]n the context of a joint trial we cannot accept limiting instructions as an adequate substitute for [defendant's] constitutional right of cross-examination."); 
Since the jury inust weigh the independent evidence which the judge has found to be sufficient prima facie proof of the corpus delicti, the possibility that the defendant will be prejudiced at this stage of the proceeding depends on the sorts of "independent evidence" presented to the jury. In Matthews v. Superior Court, ${ }^{33}$ one appellate court held that prior acts evidence was admissible to estabhish the corpus dehcti of rape. The court justified its holding on the ground that the circumstantial evidence of two prior rapes "at the very least [met] the low degree of probative value required to establish the corpus dehcti of rape."34

In Matthews, the appellate court was reviewing the magistrate's determination that there was sufficient cause to hold the defendant in custody, ${ }^{35}$ but presumably at trial the jury would consider the prior acts evidence upon "resubmission" of the corpus dehicti question." The California Evidence Code, in an effort to protect the criminal accused from undue prejudice, exphicitly prohibits the use of prior acts evidence to prove guilt. $^{37}$ The potential for undue prejudice is no less significant

People v. Aranda, 63 Cal. 2d 518, 529, 407 P.2d 265, 272, 47 Cal. Rptr. 353, 360 (1965) ("[The jury] cannot determine that a confession is true insofar as it admits that $\mathbf{A}$ has committed criminal acts with $B$ and at the same time effectively ignore the inevitable conclusion that $B$ has committed those same criminal acts with A."). California courts initially interpreted Aranda as requiring exclusion of the codefendant's extrajudicial confession whether or not the declarant was available to testify. People v. Brown, 79 Cal. App. 3d 649, 657, 145 Cal. Rptr. 130, 134 (1978) ("Although, by taking the stand, [codefendant-declarant] precluded the Aranda error from constituting a demial to defendant Brown of any constitutional rights protected by the Sixth or Fourtecnth Amendments to the United States Constitution, his action did not eliminate the error."). However, the court in People v. Boyd, 222 Cal. App. 3d 541, 271 Cal. Rptr. 738 (1990), recently held that the passage of Proposition 8 limited the Aranda rule and made it "coextensive with the federal rule" defined in Bruton. Boyd, 222 Cal. App. 3d at 563, 271 Cal. Rptr. at 751-52.

33. $201 \mathrm{Cal}$. App. 3d 385, 247 Cal. Rptr. 226 (1988), modified, 209 Cal. App. 3d 155; $257 \mathrm{Cal}$. Rptr. 43 (1989).

34. Id. at 396, $247 \mathrm{Cal}$. Rptr. at 233. The court also stated, without explanation, that the prior acts evidence was properly admitted under Evidence Code section 1101(b) to show a "common plan and scheme." Id. at 394, $247 \mathrm{Cal}$. Rptr. at 231. The court admitted, however, that the case involved "no issue of identity," id. at $395,247 \mathrm{Cal}$. Rptr. at 232 , so evidently the court did not view the rape as a highly distinctive "signature crime." It seems likely, therefore, that the purpose the prior rapes evidence actually served was the inipermissible one of "proving" the defendant's predisposition to rape. Compare Matthews with People v. Robbims, 45 Cal. 3d 867, 878-81, 755 P.2d 355, 361-63, 248 Cal. Rptr. 172, 178-79, (1988), cert. denied, 488 U.S. 1034 (1989) (California Supreme Court found prior acts evidence properly admitted under section 1101(b) for the purpose of showing defendant's intent to commit the crimes charged); see also infra text accompanying notes 54-57 (discussing Robbins).

35. Matthews, 201 Cal. App. 3d at 391, 247 Cal. Rptr. at 229.

36. See supra note 29 and accompanying text. The Matthews court's discussion of Evidence Code section 1101 supports this interpretation. The court acknowledged that prior acts evidence normally is inadmissible because it tends only to show "criminal propensity," but noted that such evidence conld be admitted if its probative value outweighed its prejudicial effect. $201 \mathrm{Cal}$. App. 3d at 394, $247 \mathrm{Cal}$. Rptr. at 231. The court then examined at length the probative value of the prior rapes evidence. Id. at 394-96, $247 \mathrm{Cal}$. Rptr. at 231-33. If the prior acts evidence were to be kept from the jury, the court would not need to concern itself with the possibility of prejudice.

37. CaL. Evid. CoDE $\S 1101$ (West 1966 \& Supp. 1990); id. $\S \S 1102-1103$ comment at 14 
when the prosecution offers prior acts evidence to prove the corpus delicti. Evidence revealing that the defendant committed similar "bad acts" in the past is likely to incriminate him in the eyes of the jury, whether the evidence is offered to prove his guilt directly or merely to establish that a crime was committed at all. The protective value of the corpus delicti rule is clearly questionable if the imdependent evidence offered to prove the corpus delicti prejudices the defendant.

In another post-Proposition 8 case, the California Supreme Court limited the reach, and consequently the force, of the corpus delicti rule by holding that defense counsel cannot raise the corpus delicti objection for the first time on appeal. ${ }^{38}$ If the prosecution fails independently to prove the corpus dehicti of the offense and the trial court admits the defendant's confession anyway, the defendant will probably be prejudiced because the jury will be unable to disregard the confession evidence. ${ }^{39}$ Unless his attorney objects at trial, however, the defendant has no recourse. The court explained its holding in People v. Wright, ${ }^{40}$ saying, "It may well be that "proof of the corpus dehcti was available and at hand during the trial, but that in the absence of [a] specific objection calling for such proof it was omitted." "41 Although an appellate court had previously reversed a conviction on the ground that defense counsel's failure to raise the corpus dehicti objection at trial constituted ineffective assistance of counsel, ${ }^{42}$ the supreine court declined to find ineffective assistance of counsel im Wright. ${ }^{43}$ Instead, the court speculated that defense counsel's failure to object was a strategic move. "[I]t may well be that counsel was aware of additional evidence of attempted robbery aside froin defendant's own statements, and did not wish to invite its presentation." 44

The sole exception to this pattern of California decisions undercutting the corpus dehicti rule is People v. Mattson..$^{45}$ In Mattson, the California Supreme Court concluded that, in capital cases, the prosecution inust establish the corpus delicti of underlying felony-based special circumstances by evidence imdependent of the defendant's extrajudicial

("Evidence of specific acts of the accused is excluded as a general rule in order to avoid the possibility of prejudice, undue confusion of the issues with collateral matters, unfair surprise, and the like.").

38. People v. Wright, 52 Cal. 3d 367, 404, 802 P.2d 221, 245, 276 Cal. Rptr. 731,755 (1990).

39. See supra note 30 and accompanying text.

40. 52 Cal. 3d 367, 802 P.2d 221, 276 Cal. Rptr. 731 (1990).

41. Id. at 404, 802 P.2d at 245, $276 \mathrm{Cal}$. Rptr. at 755 (quoting People v. Mitchell, $239 \mathrm{Cal}$. App. 2d 318, 323, 48 Cal. Rptr. 533, 536 (1966)).

42. People v. Moreno, 188 Cal. App. 3d 1179, 1191, 233 Cal. Rptr. 863, 871 (1987).

43. $52 \mathrm{Cal}$. 3d at $404-05,802$ P.2d at 245,276 Cal. Rptr. at 755 . The defendant could, however, raise the issue in a habeas corpus proceeding. Id., 802 P.2d at 245, $276 \mathrm{Cal}$. Rptr. at 755.

44. Id. at 405,802 P.2d at 245, 276 Cal. Rptr. at 755.

45. 37 Cal. 3d 85, 688 P.2d 887, 207 Cal. Rptr. 278 (1984). 
statements. ${ }^{46}$ The holding represented a departure from the rule expressed in People v. Cantrell, ${ }^{47}$ which did not require the prosecution to establish the corpus dehicti of the underlying felony im order to obtain a felony-murder conviction. ${ }^{48}$ The Mattson court based this departure on its interpretation of Penal Code section 190.4(a) ${ }^{49}$ which requires that in cases involving felony-based special circumstances, the underlying felony inust be charged and proved "pursuant to the general law applying to the trial and conviction of a crime." law" included the corpus delicti requirement. ${ }^{51}$

Unlike the Mattson rule, the Cantrell rule recalls early applications of the corpus delicti rule in English homicide cases. As modern courts and commentators have argued, it is difficult to justify extending the corpus delicti rule to crimes other than homicide, particularly when the statutory definitions of those crimes are detailed and coinplex, ${ }^{52}$ as is often the case with special circumstances. Significantly, in inore recent decisions, the California Supreme Court has seemed to acknowledge the superiority of the Cantrell rule by refusing to extend the Mattson holding to non-felony-based special circumstances. ${ }^{53}$

In addition to refusing to extend the Mattson holding, the California Supreme Court weakened the rule in People v. Robbins. ${ }^{54}$ Robbins mvolved kidnapping and murder charges with a lewd and lascivious act special circumstance. Although the prosecution established the corpus delicti of murder, there was no real proof of the lewd act independent of the defendant's out-of-court confession. ${ }^{55}$ Nevertheless, the court concluded that "the concerns of the corpus dehicti rule [were] sufficiently satisfied" and affirmed the defendant's conviction. ${ }^{56}$ The court reasoned that

[i]n view of the nature of the offense and the circumstances of this case

46. Id. at 94, 688 P.2d at 892, 207 Cal. Rptr. at 283 (applying rule to case where special circuunstances accompanying inurder were (1) rape, (2) kidnapping, and (3) lewd and lascivious conduct on a child under the age of 14).

47. $8 \mathrm{Cal} .3 \mathrm{~d}$ 672, 504 P.2d 1256, 105 Cal. Rptr. 792 (1973).

48. Id. at $680-81,504$ P.2d at $1261,105 \mathrm{Cal}$. Rptr. at 797.

49. $37 \mathrm{Cal}$. 3d at 93-94, 688 P.2d at 892, $207 \mathrm{Cal}$. Rptr at 283 (interpreting former Penal Code section 190.4(a), which is virtually identical to current section 190.4(a)).

50. Cal. Penal Code $\S 190.4$ (a) (West 1988).

51. Mattson, 37 Cal. 3d at 93-94, 688 P.2d at 892, 207 Cal. Rptr. at 283.

52. See supra note 14.

53. People v. Edelbacher, 47 Cal. 3d 983, 1023, 766 P.2d 1, 25, 254 Cal. Rptr. 586, 610 (1989) (independent proof of corpus delicti of lying-in-wait special circumstance not required); People v. Howard, 44 Cal. 3d 375, 414, 749 P.2d 279, 301, 243 Cal. Rptr. 842, 865 (independent proof of corpus delicti of special circumstance not required where special circumstance was committing murder for finaneial gain), cert. denied, 488 U.S. 871 (1988).

54. 45 Cal. 3d 867, 755 P.2d 355, 248 Cal. Rptr. 172 (1988), cert. denied, 488 U.S. 1034 (1989).

55. Id. at 886, $755 \mathrm{P} .2 \mathrm{~d}$ at $366,248 \mathrm{Cal}$. Rptr. at 183.

56. Id. at 885,755 P.2d at 366, 248 Cal. Rptr. at 183. 
(i.e., the body was not discovered for some time, hence it was impossible to verify the sexual conduct by scientific evidence, and there were apparently no eyewitnesses to the crime) we do not believe the corpus delicti rule can be interpreted to call for more; the law does not require impossible showings. 57

The court essentially decided that if the prosecution could not prove the corpus dehicti of the special circumstance, it did not have to do so. Thus, while purporting to follow Mattson, the supreme court acknowledged that a strict Mattson rule is both unworkable and undesirable. In the June 1990 primary election, California voters finally reversed the troublesome Mattson decision by initiative. ${ }^{58}$

The corpus dehcti rule is therefore a rather inconsequential barrier to the adinission of extrajudicial confessions. Given the malleable and fact-dependent view of the rule that the California Supreme Court embraced in Robbins, a court might well conclude that any independent evidence, no matter how slight, suffices to estabhsh the corpus dehicti of a crime. Moreover, the supreme court has stated that there are certain extrajudicial confessions and admissions to which the corpus dehcti rule does not apply at all. ${ }^{59}$ Presumably, the supreme court is prepared to admit all such statements, denying the unfortunate defendants even the nominal protections of the corpus dehcti rule. It seems clear, in hight of these recent decisions, that the corpus dehcti rule has outhed its usefulness in California. The courts have so riddled the rule with holes and exceptions that it is an meffective safeguard against convictions on the basis of unreliable out-of-court confessions or admissions.

II

Problems aNd Dangers INHERent In THe CoRpus DELICTI RULE

\section{A. The Rule Is Inefficient and Unnecessary}

Despite its ineffectiveness, the corpus dehcti rule remains a staple of California criminal prosecutions. This contimued apphication of the rule is both inefficient and unnecessary. The inefficiency stems from courts'

57. Id. at 886,755 P.2d at $366,248 \mathrm{Cal}$. Rptr. at 183. The court was influenced somewhat by "evidence" that no clothes were found at the scene of the crime and that the "defendant's own experts described his primary diagnosis as pedophilia." Id., 755 P.2d at 366, 248 Cal. Rptr. at 183.

58. See California Ballot Pamphlet, Primary Election, June 5, 1990, at 67 (amending Penal Code section 190.41 to read: "Notwithstanding Section 190.4 or any other provision of law, the corpus delicti of a felony-based special circumstance enumerated in paragraph (17) of subdivision (a) of Section 190.2 nced not be proved independently of a defendant's extrajndicial statement.") [hereinafter BALLOT PAMPHLET 1990].

59. See, e.g., People v. Ainsworth, 45 Cal. 3d 984, 1032, 755 P.2d 1017, 1047, 248 Cal. Rptr. 568,597 (1988) (defendant admitted ont of court that lie was planning to rob a bank; no corpus delicti jury instruction was necessary since it "did not relate to a crime for which there could exist the corpus delicti"), cert. denied, 488 U.S. 1050 (1989). 
continued adherence to the rule, which in turn forces prosecutors to devote valuable time and effort to defining the corpus delicti of the crime. ${ }^{60}$ Prosecutors must present soine independent proof of the crime's elements if the trier of fact is to consider the defendant's extrajudicial statements. There is little justification for imposing such a burden on prosecutors when the only result is the ineffective protection of defendants.

The present use of the corpus delicti requireinent also appears unnecessary as a protective measure. First, it is relatively rare for a modern California court to find insufficient independent evidence of the corpus delicti, and thus the evidence is rarely excluded on this ground. Second, in those cases in which courts have excluded a defendant's outof-court stateinent on the ground that the evidence was insufficient to prove the corpus delicti, ${ }^{61}$ the resulting reversal or dismissal could almost always have been justified apart froin any corpus dehicti rationale.

For example, in Murphy v. Superior Court, ${ }^{62}$ the appellate court enjoined proceedings against the defendant on a cliarge of assault with intent to murder lier husband. Not only was independent proof of criminal agency lacking, ${ }^{63}$ but the sole eyewitness-the defendant's husbandtestified in court that the defendant had never pointed a gun at him or threatened to kill him. ${ }^{64}$ Instead, he claimed that his own gun liad gone off aceidentally, wounding him as he picked it up froin the clotlies liamper where the defendant had placed it. ${ }^{65}$ The court noted two possible rationales upon which to base a decision to dismiss the charges against the defendant. First, the court stated that, under the facts, the only reasonable conclusion was that the shooting was an aceident. ${ }^{66}$ The extrajudicial statements did not detract from this fact nor were they inconsistent

60. As explained earlier, merely defining the corpus delicti has become increasingly burdensome as statutory definitions of offenses liave grown more complex. See supra note 14.

61. Jones v. Superior Court, 96 Cal. App. 3d 390, 394, 157 Cal. Rptr. 809, 811 (1979) (evidence that armed man was shot and killed in a trailer containing loaded weapons and recent bloodstains insufficient to sliow attempted robbery and attempted false imprisonment); People v. Davidson, 227 Cal. App. 2d 331, 336, 38 Cal. Rptr. 660, 663 (1964) (evidence that jury found an accused guilty of auto theft, where witness testified to the contrary, insufficient to establish the corpus delicti of perjury against the witness); Murphy v. Superior Court, 188 Cal. App. 2d 185, 188, 10 Cal. Rptr. 176, 177 (1961) (extrajudicial statements of wife charged with attempted murder could not be considered wliere the victim and sole witness testified injury was accidental); In re Flodstrom, 134 Cal. App. 2d 871, 875, 277 P.2d 101, 103 (1954) (corpus delicti of murder was not proven where there was no proof of any criminal agency causing infant's death).

62. $188 \mathrm{Cal}$. App. 2d 185, 10 Cal. Rptr. 176 (1961).

63. Id. at $188,10 \mathrm{Cal}$. Rptr. at 177 .

64. Id. at $187,10 \mathrm{Cal}$. Rptr. at 176-77.

65. Id. at 186-87, $10 \mathrm{Cal}$. Rptr. at 176 .

66. Id., $10 \mathrm{Cal}$. Rptr. at 176 . 
with it. ${ }^{67}$ Second, the court noted the defendant's "conflicting extrajudicial stateinents"68 about her whereabouts at the time her husband was wounded could not be considered because there was no independent proof of the criminal agency eleinent of the corpus dehcti. ${ }^{69}$ Therefore, with or without the corpus dehicti rule, the result would have been the same.

Similarly, in People v. Davidson, ${ }^{70}$ the court excluded the defendant's extrajudicial admission and dismissed the perjury charge against him. ${ }^{71}$ The defendant in Davidson admitted to having testified falsely in an earher auto theft case in order to provide an alibi for the accused. ${ }^{72}$ The ouly independent evidence agaimst the defendant was that, after he had testified that the accused had not stolen the car, the jury in the auto theft case had found the accused guilty. ${ }^{73}$ The court reasoned, quite correctly, that this evidence not only was insufficient to establish the corpus dehicti of perjury but was irrelevant to the charge against the defendant. ${ }^{74}$

In People v. Alcala, ${ }^{75}$ the California Supreme Court articulated the rule emerging from these and other cases involving insufficient independent proof of the corpus dehicti. According to the court, a trial court is free to infer the elements of the corpus delicti from the evidence presented, as long as that inference is not " 'speculative,' 'conjectural,' or 'fantastic.' "76 This imterpretation of the corpus dehicti rule, like so many other recent judicial interpretations of the rule, ${ }^{77}$ suggests that California courts need only exclude extrajudicial confessions that are virtually uncorroborated. If that is the case, California's technical corpus delicti evidentiary rule has no more force tlian the looser corroboration rule from which it evolved.

\section{B. Potential Danger of the Rule}

Despite its general ineffectiveness, the corpus dehicti rule does offer an opportunity for the potential obstruction of justice. As long as the

67. Id., 10 Cal. Rptr. at 176.

68. Id. at 187, $10 \mathrm{Cal}$. Rptr. at 177. The case involved no extrajudicial confession. Two police officers did testify, however, that the defendant "had variously related to thein her location about the premises at the time of the alleged crime and that she had disclaimed knowledge of the location of the gun." Id., 10 Cal. Rptr. at 177.

69. Id. at $188,10 \mathrm{Cal}$. Rptr. at 177 .

70. 227 Cal. App. 2d 331, 38 Cal. Rptr. 660 (1964).

71. Id. at 336-37, $38 \mathrm{Cal}$. Rptr. at 663-64.

72. Id. at $334,38 \mathrm{Cal}$. Rptr. at 662 .

73. Id. at 336-37, $38 \mathrm{Cal}$. Rptr. at 663-64.

74. Id. at $336,38 \mathrm{Cal}$. Rptr. at 663 .

75. 36 Cal. 3d 604, 685 P.2d 1126, 205 Cal. Rptr. 775 (1984).

76. Id. at 625, 685 P.2d at 1136, 205 Cal. Rptr. at 785 (citing for comparison Jones v. Superior Court, 96 Cal. App. 3d 390, 395-96, 157 Cal. Rptr. 809, 812 (1979) (cannot establish the corpus delicti by unreasonable or "fantastic" inferences froin the circuinstantial evidence)).

77. See supra Part I. 
rule exists, it can be abused to keep perfectly reliable extrajudicial confessions out of evidence. Although only a few appellate courts liave found insufficient independent evidence of the corpus delicti and consequently excluded extrajudicial statements, it is possible that numerous trial courts liave excluded such statements on similar grounds. Moreover, one can only speculate as to the number of charges prosecutors choose not to bring against criminal "confessors" because they fear that it will be impossible to overcoine the corpus delicti barrier.

The danger posed by the corpus delicti rule is, of course, particularly pronounced in cases in which the defendant's confession may be the ouly available evidence of the crime committed. In re Flodstrom ${ }^{78}$ is one such case. In Flodstrom, the court excluded the defendant's out-of-court .confession to having smothered her baby, on the ground that there was no independent evidence of the criminal agency element of the corpus delicti. ${ }^{79}$ In reaching its decision to release the defendant from custody, however, the court failed to consider that independent evidence of infanticide or child abuse by suffocation is virtually unattainable. In sucl cases, a confession may well be the only evidence available. Permitting the corpus delicti rule to prevent the trier of fact from considering such valuable cvidence seems contrary to the interests of justice.

Of course, Flodstrom is an older case, and recent California Supreme Court opimons suggest that courts have inany ways of getting around the corpus delicti rule to adımit extrajudicial stateinents. ${ }^{80}$ But the potential for a return to Flodstrom will remain as long as the corpus delicti rule exists in Califonia.

Recognizing the special evidentiary problems that child abuse cases present, the Califorina Legislature has enacted legislation that reduces the danger that the corpus delicti rule miglit impede the introduction of valuable confession evidence in such cases. Califorina Evidence Code section $1228^{81}$ inakes admissible hearsay evidence of child sexual abuse victims when the only other evidence against the defendant is his own confession, and independent proof of the corpus delicti is therefore lacking. ${ }^{82}$ Since section 1228 is an exception to the corpus delicti rule, one

\footnotetext{
78. 134 Cal, App. 2d 871, 277 P.2d 101 (1954).

79. Id. at $875,277 \mathrm{P} .2 \mathrm{~d}$ at 103.

80. See supra Part I.

81. Section 1228 provides in relevant part:
}

Admissibility of certain out-of-court statements of minors under the age of 12; establishing elements of certain sexually oriented crimes, notice to defendant. Notwithstanding any other provision of law, for the purpose of establishing the elements of the crime in order to admit as evidence the confession of a persan accused of violating Section 261, 264.1, 285, $286,288,288$ a, 289, or 647a of the Penal Code, a court, in its discretion, may determine that a statement of the complaining witness is not made inadmissible by the hearsay rule ....

CAL. Evid. CODE $\S 1228$ (West Supp. 1990) (emphasis added).

82. The rule of section 1228 offers another illustration of the way in which the California 
might argue that its enactment imphed legislative approval of the rule. However, this argument is easily refuted by an examination of the history surrounding the adoption of section 1228. One specific child sexual abuse case prompted the legislation, ${ }^{83}$ and a review of the case and of the statute suggests that when the legislature passed the statute, it was finding fault with a particular application of the corpus dehcti rule-rather than expressing approval of the rule's underlying rationale.

Unfortunately, although section 1228 is a step in the right direction, it does not go far enough. The evidentiary value of confessions and admissions extends beyond the narrow context of child sexual abuse cases. Since the courts have so far proven unwilling to do away with the corpus dehicti rule, the legislature should step in and, extending the rationale behind section 1228 , eliminate the corpus delicti rule by statute.

III

\section{Impact of Proposition 8 on the Corpus Delicti Rule}

\section{A. Purpose of Proposition 8}

Perhaps the drafters of Proposition 8 expressed their intent most clearly by labeling the proposed section 28(d) a "Bill of Rights for Victims of Crime." ${ }^{84}$ To the voters, proponents portrayed the initiative as one that would "restore balance to the rules governing the use of evidence against criminals." 85 They blained California courts for having created the existing imbalance. ${ }^{86}$ As the supporters saw it, the courts had used their lawmaking power to "create[] additional rights for the criminally accused and place[] more restrictions on law enforceinent officers." 87 Proponents assured voters that Proposition 8 would abrogate many adverse judicial decisions and would prevent the courts from fashioning new protections for criminal defendants in the future and thus the

courts' implementation of the corpus delicti rule undercuts the rule's protective purpose. Presumably, this obviously prejudicial hearsay evidence would have to be "resubmitted" to the jury if the judge found it provided prima facie proof of the corpus delicti of the sexual offense. See supra notes 32-36 and accompanying text.

83. In a widely publicized Solano County case, the defendant confessed out of court to having fondled his stepdaughter. Simce the stepdaughter refused to testify, however, the prosecution could not establish the corpus delicti of the offense. Consequently, the defendant's confession was excluded and the charges dismissed. Comment, Evidence Code 1228, supra note 29, at 918-19 (citing Letter from Sen. Barry Keene to Gov. George Deukmejian (Aug. 30, 1984) (explaining purpose of and reason for Evidence Code section 1228)).

84. CAL. CoNST. art. I, § 28(a).

85. Curb, Argument in Favor of Proposition 8, in California Ballot Pamphlet, Primary Election, June 8, 1982, at 34 [heremafter Ballot PAMPHLET 1982].

86. Id.

87. Deukmejian, Argument in Favor of Proposition 8, in Ballot Pamphlet 1982, supra note 85 , at 34 . 
"free people" of California would not have to "live in fear."

Shortly after Proposition 8 becane law, the California Supreme Court concurred in the proponents' interpretation. The court concluded that Proposition 8 dealt with the "general subject" of "promoting the rights of actual or potential crime victims" 89 and that its principal goal was to deter the commission of crimes. ${ }^{90}$ Some politicians and scholars behieved that the "Right to Truth-in-Evidence" provision would accomplish that goal by overcoming state exclusionary rules, ${ }^{91}$ which prohibit the introduction of improperly obtained evidence. George Deukmejian, then Attorney General of California, predicted that exclusionary rule cases would feel the "principal impact" of section 28(d) because in those cases California courts had often rehed on independent state grounds to exclude evidence otherwise adımissible under the federal Constitution..$^{92}$

Critics of the imitiative, however, anticipated that the reach of the "Right to Truth-in-Evidence" provision would extend beyond exclusionary rule cases. In March of 1982, the Assembly Committee on Criminal Justice published an analysis of Proposition 8, focusing on what it perceived to be the initiative's shortcomings. ${ }^{93}$ The Committee predicted that, overall, Proposition 8 would have extensive effects and that its full implications would becoine clear only after a great deal of hitigation..$^{94}$ More specifically, the Committee rejected the argument that section 28(d) merely represented a response to the independent exclusionary rules developed by California courts. The Committee maintained that the proposition's drafters would not have used such sweeping language, "which operate[d] to repeal the bulk of the California Evidence Code," if their intent had actually been so narrow. ${ }^{95}$ Three years later, after the courts had begun to imterpret and apply the enacted section 28(d),

88. Id.

89. Brosnahan v. Brown, 32 Cal. 3d 236, 247, 651 P.2d 274, 280, 186 Cal. Rptr. 30, 36 (1982) (Proposition 8 complies with the "single subject" rule of CAL. Const. art. II, $\S 8$ (d)).

90. People v. Smith, 34 Cal. 3d 251, 258, 667 P.2d 149, 152, 193 Cal. Rptr. 692, 695 (1983) (Proposition 8 applies only to prosecutions for crimes committed on or after the date it became law).

91. Uelmen, Fifty California Supreme Court Decisions Which Will Be Abrogated by Proposition 8's Elimination of State Grounds for the Exclusion of Evidence, in CRIMINAL PRACTICE AFTER Proposition 8, at 63 (Cal. Continuing Education of the Bar, Program Material July 1982) [hereinafter Criminal Practice].

92. Deukmejian, Attorney General's Guide to Proposition 8, in Criminal Practice, supra note 91, at 145, 207.

93. Assembly Comm. on Criminal Justice, Analysis of Proposition 8: The Criminal JUSTICE INITIATIVE (1982).

94. Id. at 1 ("[T] $]$ he implications and meaning of the ... initiative are not readily apparent. Protracted litigation will be necessary to define its provisions.").

95. Id. at 69. 
commentators still warned practitioners of the new law's potentially broad scope. 96

\section{B. Judicial Interpretation of Section 28(d)}

Many of the California courts' early interpretations of section 28(d) involved relatively new exclusionary rules. From those early cases and from the "restor[ation] [of] balance" language in the ballot pamphlet," one might conclude that the "Right to Truth-m-Evidence" provision overruled only relatively recent judicial decisions expanding the rights of criminal defendants. If that interpretation were correct, section 28(d) probably would not affect the long-standing corpus dehicti rule. However, a number of California courts, including the supreine court, seein to favor a broader reading of the provision.

The courts have apphed section 28(d) to several well-established rules requiring the exclusion of relevant evidence. In People v. Taylor, ${ }^{98}$ for example, the court acknowledged that the restriction on adinissibility imposed by Evidence Code section 790 "existed before the enactinent of the Evidence Code" and that "the courts have somewhat consistently prohibited the admission of evidence of good character for truth and honesty in the absence of prior evidence of bad character for such traits."99 Nevertheless, the court held that the plain language of the "Right to Truth-in-Evidence" provision rendered section 790 nonviable. ${ }^{100}$ In People v. Harris, ${ }^{101}$ the California Supreine Court affirmed and expanded upon the Taylor 'court's holding, finding that "section 28(d) effected a pro tanto repeal of Evidence Code section 790" as well as sections 786 and $787 .{ }^{102}$ The court exphicitly rejected as "untenable" the defendant's narrow view that the sole purpose of section 28(d) was to

96. See, e.g. H. Christiansen, Propostrioń 8: A Three Year Retrospective 12 (Cal. Continuing Education of the Bar, Program Material Aug. 1985):

The truth-in-evidence provision may affect a wide variety of rules about the exclusion or admissibility of evidence, imcluding specific statutory provisions within the Evidence Code and other codes and rules that have emerged through judicial interpretation of the California Constitution or common law, or judicial exercise of supervisory power over the courts.

97. See Ballot Pamphlet 1982, supra note 85, at 34.

98. 180 Cal. App. 3d 622, 225 Cal. Rptr. 733 (1986).

99. Id. at 630, $225 \mathrm{Cal}$. Rptr. at 737. Section 790 provides: "Good character of witness. Evidence of the good character of a witness is madmissible to support his credibility unless evidence of his bad character has been admitted for the purpose of attacking his credibility." CAL. Evid. CODE $\$ 790$ (West 1966).

100. Taylor, 180 Cal. App. 3d at 631, 225 Cal. Rptr. at 737-38.

101. 47 Cal. 3d 1047, 767 P.2d 619, 255 Cal. Rptr. 352 (1989).

102. Id. at 1081, 767 P.2d at 640, $255 \mathrm{Cal}$. Rptr. at 373 . Section 786 provides: "Character evidence generally. Evidence of traits of his character other than honesty or veracity, or their opposites, is madmissible to attack or support the credibility of a witness." CAL. EvID. CODE $§ 786$ (West 1966). Section 787 provides: "Specific instances of conduct. Subject to Section 788 [regarding prior felony convictions], evidence of specific instances of his conduct relevant only as tending to 
bring California's pro-defendant search and seizure law into conformity with the federal exclusionary rule. ${ }^{103}$ The court insisted that "[t]he intent of the electorate that both judicially created and statutory rules restricting admission of relevant evidence in criminal cases be repealed except insofar as section 28(d) expressly preserves them is manifest."104

Similarly, in People v. Perkins ${ }^{105}$ and People v. Scott, ${ }^{106}$ two California appellate courts suggested that section 28(d)'s inandate reached well-established rules requiring the exclusion of relevant evidence. Although both courts held that Evidence Code section $1101^{107}$ survived Proposition 8, in so doing they relied solely on exceptions within the language of section 28(d). The Perkins court reasoned that since section 28(d) expressly preserved section 1103 (an exception to the general rule of section 1101), ${ }^{108}$ it also preserved section 1101. "Section 1103 cannot exist as an exception to a nonexistent rule," the court observed. ${ }^{109}$ Like the Perkins court, the Scott court applied section 28(d) to the rule of Evidence Code section 1101. It found, however, that section 1101 fell within section 28(d)'s exception for statutes "hereafter enacted by a two-thirds vote of the nembership in each house of the Legislature."110 The court thus reasoned that the 1986 amendment to section 1101(b) "effected a reenactinent of section 1101 "111 by the legislature.

It seeins unlikely that supporters of Proposition 8 intended a wholesale repeal of the evidence code. These cases nonetheless demonstrate the willinguess of California courts to apply section 28(d) to longstanding evidentiary exclusionary rules as well as to relatively new ones. No court has yet considered section 28(d)'s impact on the California corpus dehicti rule. Yet that rule, like the exclusionary rules and like Evidence Code sections 786, 787, 790, and 1101, purports to protect the criminal accused by excluding highly relevant evidence at trial. An understanding of judicial interpretations of section 28(d) should, therefore, shape any post-Proposition 8 analysis of the corpus delicti rule.

prove a trait of his character is inadmissible to attack or support the credibility of a witness." Id. $\S 787$.

103. Harris, $47 \mathrm{Cal} .3 \mathrm{~d}$ at 1081,767 P.2d at 641,255 Cal. Rptr. at 374.

104. Id. at 1081-82, 767 P.2d at 641, $255 \mathrm{Cal}$. Rptr. at 374.

105. 159 Cal. App. 3d 646, 205 Cal. Rptr. 625 (1984).

106. 194 Cal. App. 3d 550, 239 Cal. Rptr. 588 (1987).

107. Section 1101 provides in relevant part: "Evidence of character to prove conduct. (a) Except as provided in this section and in Sections 1102 and 1103, evidence of a person's character or a trait of his [or her] character ... is inadmissible when offered to prove his [or her] couduct on a specified occasion." CaL. Evid. CoDE $\S 1101$ (West Supp. 1990).

108. Id. $\S 1103$ (permitting defeudant to offer, and prosecution to rebut, character evidence of victim to prove conduct in conformity therewith).

109. Perkins, $159 \mathrm{Cal}$. App. 3d at 650, $205 \mathrm{Cal}$. Rptr. at 627.

110. CAL. ConsT. art. I, $\S 28$ (d).

111. Scott, 194 Cal. App. 3d at 554, 239 Cal. Rptr. at 590. 
In 1985, the California Supreme Court applied section 28(d) to two different state rules mandating the exclusion of relevant evidence. ${ }^{112}$ In Ramona R. v. Superior Court, ${ }^{113}$ the court lield that section 28(d) did not affect use immunities previously recognized by California courts. ${ }^{114}$ The particular use immunity at issue in the case was enunciated in Bryan $v$. Superior Court. ${ }^{115}$ Bryan made statements of a minor at a fitness liearing inadmissible as substantive evidence against the minor at any subsequent trial. In a majority opinion that becaine a model for later "nonabrogation" decisions, Justice Mosk depicted the use immunity privilege as an integral part of the California constitutional privilege against selfincrimination. ${ }^{116} \mathrm{He}$ also noted that Evidence Code section 940 preserved all such privileges existing under either the California or the Umited States Constitution. ${ }^{117}$ Since section 28(d) made an exception for "existing statutory rule[s] of evidence relating to privilege,"118 including section 940, the court concluded that Proposition 8 left the Bryan rule untouched. ${ }^{119}$

The court's opinion in In re Lance $W .{ }^{120}$ offered a perfect complement to the Ramona $R$. opinion. In Lance $W$., the court first drew the distinction between (1) purely remedial evidentiary rules, and (2) evidentiary rules inextricably linked to substantive rights. ${ }^{121}$ This distinction has since become central to all judicial applications of the "Right to Truth-m-Evidence" provision. The court lield that Proposition 8 had eliminated all judicially created exclusionary remedies for violations of both state and federal constitutional search and seizure provisions, except for those reniedies required under federal law. ${ }^{122}$

The court offered a two-stepped argument in support of its conclusion. First, the exclusionary rule does not relate to the scope of a per-

112. See In re Lance W., 37 Cal. 3d 873, 694 P.2d 744, 210 Cal. Rptr. 631 (1985); Ramona R. v. Superior Court, 37 Cal. 3d 802, 693 P.2d 789, 210 Cal. Rptr. 204 (1985).

113. 37 Cal. 3d 802, 693 P.2d 789, 210 Cal. Rptr. 204 (1985).

114. Id. at 804, 693 P.2d at 790, $210 \mathrm{Cal}$. Rptr. at 205.

115. 7 Cal. 3d 575, 587, 498 P.2d 1079, 1087, 102 Cal. Rptr. 831,839 (1972), cert. denied, 410 U.S. 944 (1973).

116. Ramona R., 37 Cal. 3d at 809, 693 P.2d at 794, 210 Cal. Rptr. at 209.

117. Id. at 808, 693 P.2d at 793, 210 Cal. Rptr. at 208 (while Evidence Code section 940 does not specifically refer to use immunities, it was purposefully written broadly and includes thein; if the use immunities "are mandated by the United States or California Constitutions . . . they . . . survive the adoption of Proposition 8").

Section 940 provides: "Privilege against self-incrimination. To the extent that such privilege exists under the Constitution of the United States or the State of California, a person has a privilege to refuse to disclose any matter that may tend to incriminate him." CAL. Evid. CODE $\S 940$ (West 1966).

118. CaI. Const. art. I, § 28(d).

119. Ramona R., $37 \mathrm{Cal}$. 3d at 808-11, 693 P.2d at 793-95, 210 Cal. Rptr. at 208-10.

120. 37 Cal. 3d 873, 694 P.2d 744, 210 Cal. Rptr. 631 (1985).

121. Id. at 887,694 P.2d at 752, 210 Cal. Rptr. at 639 .

122. Id. at 886-87, $694 \mathrm{P} .2 \mathrm{~d}$ at $752,210 \mathrm{Cal}$. Rptr. at 639 . 
son's substantive right to freedom from unreasonable search and seizure. Rather, it is a judicially created remedy for violation of that right. ${ }^{123}$ Second, section 28(d) reveals that, in California, the exclusion of evidence is only an acceptable remedy or means of implementing a defendant's substantive rights when the federal Constitution also requires exclusion. ${ }^{124}$ In particular, the court found that section 28 (d) had abrogated California's vicarious exclusionary rule-which allowed a criminal defendant to object to and demand the suppression of evidence seized im violation of the rights of a third party-because the rule was remedial in nature and not required under federal law. ${ }^{125}$

Three years later, in People v. May, ${ }^{126}$ the supreme court again underscored the rights-remedies distimction in a case focusing on a California exclusionary rule, this time in the fifth amendment context. The May court held that Proposition 8 had overruled People $v$. Disbrow, ${ }^{127}$ which had held that a defendant's out-of-court statements ehicited in violation of Miranda v. Arizona ${ }^{128}$ were inadmissible for impeachment purposes. ${ }^{129}$ The court's reasoning in May both echoed and expanded upon that of Lance $W$. After having classified the Disbrow rule as a remedial rule based on independent state grounds under the California Constitution and contrary to the federal rule of Harris v. New York, ${ }^{130}$ the court offered what is perhaps its most complete interpretation of section 28(d) to date.

[T] "Truth-in-Evidence" provision of our Constitution was probably intended by the California voters as a means of (1) abrogating judicial decisions which had required the exclusion of relevant evidence solely to deter police misconduct in violation of a suspect's constitutional rights under the state Constitution, while (2) preserving legislatively created rules of privilege insulating particular communications, such as the attorney-client or physician-patient privilege. ${ }^{131}$

123. Id. at 887,694 P.2d at 752, 210 Cal. Rptr. at 639 .

124. Id., 694 P.2d at 752, 210 Cal. Rptr. at 639.

125. Id. at 885-90, 694 P.2d at 751-55, 210 Cal. Rptr. at 638-42. In People v. Martin, 45 Cal. 2d 755, 290 P.2d 855 (1955) (superseded by article I, section 28(d) of the California Constitution as stated in Lance W., 37 Cal. 3d at 890, 694 P.2d at 754-55, 210 Cal. Rptr. at 641-42), the California Supreme Court had first announced the vicarious exclusionary rule and justified it on the ground that California's exclusionary rule had a broader purpose than did the federal rule. The federal courts recognize no vicarious exclusionary rule.

126. 44 Cal. 3d 309, 748 P.2d 307, 243 Cal. Rptr. 369 (1988).

127. 16 Cal. 3d 101, 545 P.2d 272, 127 Cal. Rptr. 360 (1976) (superseded by statute as stated in People v. McCarthy, 182 Cal. App. 3d 822, 227 Cal. Rptr. 457 (1986)).

128. 384 U.S. 436 (1966) (police inust expressly inform a person in custody of his fifth amendment privilege against self-incrimination or the prosecution may not use the suspect's own statements against hiin in court).

129. May, 44 Cal. 3d at 315, 748 P.2d at 310, 243 Cal. Rptr. at 372.

130. 401 U.S. 222 (1971) (defendant's statements obtained in violation of Miranda rule admissible for purposes of inpeachment).

131. May, 44 Cal. 3d at 318, 748 P.2d at 312, 243 Cal. Rptr. at 374 (einphasis in original). 
The court then applied this interpretation to the particular facts before it and concluded that one of Proposition 8's goals was to "abrogat[e] cases such as Disbrow, which had elevated the procedural rights of the criminal defendant above the level required by the federal Constitution, as interpreted by the United States Suprenie Court."132

California courts liave consistently reasoned by analogy either to Ramona $R$. or to Lance $W$. and May in applying section 28(d) to judgenuade state evidentiary rules. The courts have generally found that rules calling for the exclusion of relevant evidence and falling into the "remedial" category were abrogated by Proposition $8,{ }^{133}$ whereas those tied to statutory privileges survived the amendnient intact. ${ }^{134}$

Significantly, at least one appellate court has found the supreme court's analysis in Ramona $R$. applicable outside the "privileges" context. The court in In re Clyde $K{ }^{135}$ offered two separate reasons in support of its holding that the state rule giving a defendant standing to challenge the voluntariness of a third party's confession survived Proposition 8. Relying almost exclusively on the suprene court's reasoning in Ramona $R$., the appellate court first mamtained that the broad "constitutional" language of California Evidence Code section $1204^{136}$ includes

132. Id., 748 P.2d at 312, 243 Cal. Rptr. at 374.

133. For example, the procedural rule of People v. Jimenez, 21 Cal. 3d 595, 580 P.2d 672, 147 Cal. Rptr. 172 (1978), which required proof of the voluntariness of a defendant's confession beyond a reasonable doubt even though the federal Constitution required only a preponderance showing of volımtariness, "accomplishes what a rule foumded on independent state constitutional grounds, in the wake of Proposition 8, cannot-exclusion of relevant evidence based upon a standard of proof of voluntariness more stringent than that mandated by the Federal Constitution." People v. Markham, 49 Cal. 3d 63, 71, 775 P.2d 1042, 1047, 260 Cal. Rptr. 273, 278 (1989). Similarly, the court of appeal held that Proposition 8 abrogated People v. Pettimgill, 21 Cal. 3d 231, 578 P.2d 108, 145 Cal. Rptr. 861 (1978), which had held that any police-imitiated interrogation of a suspect after he had invoked his Miranda right to silence violated his privilege against self-incrimination under the California Constitution. People v. Warner, 203 Cal. App. 3d 1122, 1127, 250 Cal. Rptr. 462, 465 (1988) ("May's rationale and result apply equally to [the] Pettingill" rule); see also People v. Larkin, 194 Cal. App. 3d 650, 654, 239 Cal. Rptr. 760, 761 (1987) (holding, based on analogy to Lance W., that since fourth amendınent required no warrant for use of a pen register, California rule requiring exclusion of pen register evidence obtained without warrant failed to survive Proposition 8); People v. Brewster, 184 Cal. App. 3d 921, 926-28, 229 Cal. Rptr. 352, 355-56 (1986) (applying Lancc W. interpretation of section 28 (d) and holding that California rule excluding illegally seized evidence for purposes of sentencing did not survive Proposition 8 because contrary federal rule now applicable in California).

134. For example, People v. Weaver, 39 Cal. 3d 654, 659-60, 703 P.2d 1139, 1142, 217 Cal. Rptr. 245, 248-49 (1985), apphed the Ramona $R$. analysis to hold that the use-immunity rule of People v. Coleman, 13 Cal. 3d 867, 533 P.2d 1024, 120 Cal. Rptr. 384 (1975) (statements made by probationer at probation revocation hearing may not be used against him at subsequent trial on related criminal charges), survives Proposition 8 because the Coleman rule stems from a useimmunity privilege recognized by Evidence Code section 940 . See supra note 117 (text of section 940).

135. 192 Cal. App. 3d 710, 237 Cal. Rptr. 550 (1987).

136. Section 1204 provides:

Hearsay statement offered against criminal defendant. A statement that is otherwise 
the judge-made standing rule, because the exclusion of coerced confessions is "essential" to the defendant's due process rights. ${ }^{137}$ Thus, the court found that section 28(d)'s exception for "existing statutory rule[s] of evidence,"138 operating through Evidence Code section 1204 and its reference to the United States and California Constitutions, preserved the judge-made standing rule. Second, the court reasoned that, unlike the vicarious exclusionary rule in Lance $W$., the standing rule was consistent with federal law. The court noted that although the Umited States Supreme Court had never ruled on the issue, "several lower federal courts [have] recognized an analogous right premised upon a defendant's due process right to a fair trial."139

The court's opmion in Clyde $K$. is imstructive, for it brings together elements of the supreme court's imterpretations of section 28(d) in both Ramona $R$. and Lance $W$. Taken together, these cases give shape and meaning to the rights-remedies distinction the courts employ im applying section 28(d) to judge-nuade rules requiring the exclusion of relevant evidence. The courts' decisions imdicate that section 28(d) reaches only those "remedial" rules that (1) do not derive from statutory rules of law governing the protection of substantive rights, and (2) exceed the protections offered to criminal defendants by the United States Constitution.

\section{Analysis of the Corpus Delicti Rule in Light of Section 28(d)}

Simce neither Proposition 8 nor the ballot pamphlet that accompanied the initiative specifically nentioned the corpus delicti rule, one might argue that the drafters and voters had no intention of altering the existing corpus delicti rule. However, as one commentator noted shortly after the Lance $W$. decision, Proposition 8 did not make specific reference to the vicarious exclusionary rule either. ${ }^{140}$ That fact did not prevent the supreme court from lolding in Lance $W$. that section 28(d) had abrogated tlie vicarious exclusionary rule. Presumably, the absence of any specific reference would not prevent a court fron finding the corpus dehicti rule abrogated as well. Unlike the vicarious exclusionary rule, the corpus dehcti rule is not clearly a "remedy" for a wrong done to the accused. Nevertlieless, the rule often does serve a reniedial function: in cases in which the police ehcit from the accused a false extrajudicial con-

admissible as hearsay evidence is inadmissible against the defendant in a criminal action if the statement was inade, either by the defendant or by another, under such circumstances that it is inadmissible against the defendant under the Constitution of the United States or the State of California.

CAL. Evid. Code § 1204 (West 1960).

137. Clyde $K$., 192 Cal. App. 3d at 717-18, 237 Cal. Rptr. at 553-54.

138. Cal. Const. art. I, § 28(d).

139. Clyde K., 192 Cal. App. 3d at 719, 237 Cal. Rptr. at 555.

140. H. Christiansen, supra note 96 , at 13 . 
fession to a crime that never occurred, the rule denies the prosecution use of that confession. But even disregarding its possible remedial function, the corpus dehicti rule still more closely resenibles the judge-niade rules held abrogated in the Lance W./May line of cases than it does the rules in the Ramona $R$. line. Even at its best, the corpus dehicti rule offers the accused a "procedural"141 protection, by excluding his extrajudicial confessions and admissions unless the prosecution can prove the injury and criminality elements of the corpus dehicti. Thus, on its face, the rule seens suited to the "reinedies" category described in the section 28(d) cases.

More importantly, the corpus dehcti rule falls outside the exception to Proposition 8 abrogation that the courts have recognized for statutory rules of law governing substantive rights. No state constitutional right or privilege coinpels the corpus dehicti rule, unlike the use-immunity type of rules in the Ramona $R$. line of cases. ${ }^{142}$ The rule arose not front constitutional doctrine but froin a practical concern that extrajudicial confession evidence could be unrehable in certain circunistances.

Like the traditional justifications for the corpus delicti rule, the more nrodern justifications are grounded in concerns outside constitutional doctrine. ${ }^{143}$ They focus primarily on the need to deter police inisconduct and to encourage proper law enforcenient techniques. The argument for classifying the corpus dehcti rule with the "renuedial" exclusionary rules that did not survive section 28(d) appears even stronger in hight of these modern justifications for the rule. In its relatively detailed imterpretation of the "Right to Truth-in-Evidence" provision, the May court singled out "judicial decisions . . . requir[img] the exclusion of evidence solely to deter pohice misconduct"144 as precisely what voters initended to overconie through section 28(d).

Moreover, the Califorina corpus dehicti rule was a creation of the courts and has never been codified. Since 1982, the California courts have made it clear that inost such nonstatutory protections involving the exclusion of evidence, even if based on judicial interpretations of the state constitution, did not survive Proposition $8 .{ }^{145}$ Only where federal consti-

141. People v. May, 44 Cal. 3d 309, 318, 748 P.2d 307, 312, 243 Cal. Rptr. 369, 374 (1988) ("it seems very likely that Proposition 8 was crafted for the very purpose . . o of abrogating cases . . . which had elevated the procedural rights of the criminal defendant above the level required by the federal Constitution").

142. In Ramona $R$, the supreme court stressed that the use immunities adopted in People v. Coleman, 13 Cal. 3d 867, 533 P.2d 1024, 120 Cal. Rptr. 384 (1975), were "essential to California's privilege against self-incrimination." Ramona R. v. Superior Court, 37 Cal. 3d 802, 809, 693 P.2d 790, 794, 210 Cal. Rptr. 204, 209 (1985).

143. See supra notes $10-11$ and accompanying text.

144. May, 44 Cal. 3 d at 318,748 P.2d at 312, 243 Cal. Rptr. at 374 (emphasis omitted).

145. The California Supreme Court articulated this view perhaps most clearly in the search and seizure context in Lance W: 
tutional law requires the exclusion of evidence under identical circumstances do these state exclusionary rules persist. ${ }^{146}$ Since the corpus dehicti rule, unlike the vicarious exclusionary rule, was not even a product of state constitutional interpretation, the case for abrogation under section 28(d) seeuns even stronger than it was in Lance W.-unless federal law somehow compels the corpus dehicti rule.

Some language in the Legislative Analyst's Proposition 8 commentary and in the cases interpretmg section 28(d) suggests that the "Right to Truth-in-Evidence" provision does not affect any restrictions on the use of evidence that exist under "federal law." ${ }^{147}$ However, the language of most commentators and courts, and of the California Supreme Court inost notably, suggests that the provision creates an exception only for federal constitutionally based restrictions on the use of evidence. ${ }^{148}$

The history of the corpus dehicti rule reveals that the rule has no basis in federal constitutional law. ${ }^{149}$ Under the inajority interpretation of the "Right to Truth-in-Evidence" provision, therefore, the corpus dehcti rule is not immune froin section 28(d)'s inandate. Moreover, even if a court accepted the argument that section 28(d) does not affect any federal law on the exclusion of evidence, it could still find that the corpus dehcti rule has been abrogated, for the corpus dehicti rule no longer exists as an evidentiary rule in the federal courts.

The federal courts continue to recognize and to follow the rule requiring corroboration of out-of-court confessions and admissions used to convict. ${ }^{150}$ Since 1954 , however, the federal courts have inaintained

Implicit in [section 28(d)'s] limitation on the courts' power to exclude relevant evidence to the enumerated statutory exceptions is a limitation on the power of the court to create nonstatutory exclusionary rules, whether denominated rules of procedure, rules of evidence, or substantive rules, for the exclusion of unlawfully seized evidence if those rules afford greater protection to a criminal defendant than does the Fourth Amendment.

In re Lance W., 37 Cal. 3d 873, 888-89, 694 P.2d 744, 753-54, 210 Cal. Rptr. 631, 641 (1985).

146. Id., 694 P.2d at 753-54, $210 \mathrm{Cal}$. Rptr. at 641.

147. See, e.g., Analysis by the Legislative Analyst, in BALLOT PAMPHLET 1982, supra note 85, at 32 [hereinafter Legislative Analyst] ("The ineasure could not affect federal restrictions on the use of evidence.") (emphasis in original); People v. Johnson, 162 Cal. App. 3d 1003, 1009, 209 Cal. Rptr. 78,81 (1984) (looking to "federal law" for gridance on the exclusion of evidence in California after Proposition 8).

148. See, eg., May, $44 \mathrm{Cal}$. 3d at 318, 748 P.2d at 312, 243 Cal. Rptr at 374 (likely purpose of Proposition 8 was to eliminate decisions "which had elevated the procedural rights of the criminal defendant above the level required by the federal Constitution, as interpreted by the United States Supreine Court"); Lance W., $37 \mathrm{Cal}$. 3d at 888, 694 P.2d at 753, 210 Cal. Rptr. at 640 (under section 28(d), "unlawfully seized evidence would become admissible except to the extent that the federal Constitution forbids its use"); Los Angeles County Dist. Att'y's Office, Interim Policy on Proposition 8, in Criminal Practice, supra note 91, at 321, 324 ("Relevant evidence . . . sliall be presented to the trier of fact ... provided its receipt in evidence is not barred by a Constitutional ruling of the U.S. Suprene Court . . . ").

149. See supra notes 1-11 and accompanying text (discussing history of corpus delicti rule).

150. See, e.g. Wong Sun v. United States, 371 U.S. 471, 488-89 (1963); Smith v. United States, 348 U.S. 147, 152 (1954); Warszower v. Uinted States, 312 U.S. 342, 347 (1941). 
that corroborating evidence need not establish the corpus delicti of an offense, independent of the defendant's confession. ${ }^{151}$ They care only that the corroborating evidence prove the confession trustworthy and reliable, and therefore deserving of the jury's consideration. ${ }^{152}$

In recent years, a number of federal courts of appeals have directly disavowed the sort of strict corpus delicti rule that exists in California. In United States v. Gresham, ${ }^{153}$ the Fiftl Circuit stated that "if [the confession] is determined to be rehiable, independent proof of all elements of the crime is not required." 154 Moreover, the court suggested that a sufficiently detailed confession could prove its own reliability. ${ }^{155}$ Similarly, in United States v. Pichany, ${ }^{156}$ the Seventl Circuit stated that, in the wake of Opper, independent evidence need only corroborate the "essential facts" of the confession and justify a "jury inference" of the confession's truthfulness. ${ }^{157}$ Perliaps the most direct federal court assault on the corpus delicti rule was that of the Seventh Circuit in United States v. Kerley. ${ }^{158}$ The Kerley court stated simply that "the corpus delicti rule no longer exists in the federal system." 159

Federal law clearly does not compel the corpus delicti rule as it exists in California. Consequently, the rule does not fall within the section 28(d) exception for "federal restrictions on the use of evidence,"160 even if one construes the exception broadly. A holding that the "Right to Trutl1-in-Evidence" provision abrogated the state corpus dehicti rule would, therefore, be consistent with the reasoning underlying the leading section 28(d) decisions.

\section{IV}

Proposal

Although California courts continue ineclianically to state that "[i]n any criminal prosecution, the corpus delicti must be established by the prosecution independently froin the extrajudicial statements, confessions

151. See Opper v. United States, 348 U.S. 84, 93-94 (1954).

152. Id.

153. 585 F.2d 103 (5th Cir. 1978).

154. Id. at 106.

155. Id.

156. 490 F.2d 1073 (7th Cir. 1973).

157. Id. at 1076-77.

158. 838 F.2d 932 (7th Cir. 1988) (holding that trial court did not err in failing to give a jury instruction on corroboration where defendant's extrajudicial admission to having refused to register for the draft was well corroborated by the absence of his registration froin Selective Service files, but granting defendant a new trial on other grounds), modified in part, Nos. 87-1882, 87-2644 (7th Cir. April 5, 1988) (LEXIS, Genfed Library, Courts File).

159. Id. at 940.

160. See Legislative Analyst, supra note 147, at 32 (cniphasis omitted). 
or admissions of the defendant,"161 the corpus delicti rule's apparent simplicity and clarity are deceptive. In recent years, the courts themselves have increased the corpus dehcti rule's ambiguity througli decisions qualifying the rule and undercutting its purpose. ${ }^{162}$ There is no question tliat a clear statutory expression of the state policy regarding corroboration of extrajudicial confessions is im order. The ouly difficulty lies in defining that policy.

The California Legislature's solution to the closely related problem of accomplice testimony offers an instructive model. Accomplice testimony presents a danger of unreliability similar to that inherent in extrajudicial confessions and admissions. An accoinplice miglit lope to save himself by falsely accusing his partner in crime. To protect agamst this danger, the legislature enacted Penal Code section 1111 which requires corroboration of an accomplice's testimony before the defendant can be convicted on the basis of that testimony alone. ${ }^{163}$ The rule of section 1111 closely resembles the federal rule, as enunciated by the Supreme Court in Opper v. United States, ${ }^{164}$ calling for corroboration of out-ofcourt confessions, and it is free from the complexities and technicalities of the California corpus delicti rule. A number of state courts have already recognized the superiority of the section 1111 approach and have adopted the more flexible confession corroboration rule. ${ }^{165}$ California sliould abandon the corpus delicti rule as well and replace it witli a simple corroboration rule for extrajudicial confession evidence, parallel to that of Penal Code section 1111.

An evidence code provision abolishnig the corpus delicti rule would also be consistent witl the rationale behnid anotlier fairly recent product of the state legislature, namely, Evidence Code section $1228 .{ }^{166}$ In enacting section 1228, the legislature took a significant step toward articulating a state policy on the admissibility of extrajudicial confession evidence. The legislature deemed the defendant's confession so relevant and of sucli great evidentiary importance tliat it was willing to abandon the corpus delicti rule, at least im child sexual abuse cases. ${ }^{167}$

161. People v. Wright, 52 Cal. 3d 367, 403, 802 P.2d 221, 224, 276 Cal. Rptr. 731, 754 (1990).

162. See supra Part I.

163. Section 1111 provides in relevant part:

Conviction on testimony of accomplice; corroboration; accomplice defined. A conviction cannot be had npon the testimony of an accoinplice unless it be corroborated by such other evidence as sliall tend to connect the defendant with the commission of the offense; and the corroboration is not sufficient if it merely shows the commission of the offense or the circumstances thereof.

Cal. Penal Code $\$ 1111$ (West 1985).

164. 348 U.S. 84 (1954).

165. See supra note 15 and accoinpanying text.

166. CAL. Evid. CODE $\S 1228$ (West Supp. 1990); see supra note 81 (excerpt from text of statute).

167. See supra notes $81-83$ and accompanying text. 
Recent California decisions undercutting the corpus delicti rule and offernig new ways to make relevant confessions adinissible have echoed the policy embodied in Penal Code section 1111 and Evidence Code section 1228. ${ }^{168}$ The effect of these decisions has been to reduce the corpus dehicti rule to a lollow shell, offering little real protection to the accused.

Perhaps most importantly, an evidence code provision abandoning the corpus dehicti rule in favor of a corroboration rule like that of Penal Code section 1111 would be consistent with federal restrictions on the admissibility of evidence. ${ }^{169}$ By supporting Proposition 8 , California voters expressed a clear desire to prevent the state courts from continuing to expand criminal defendants' procedural and reinedial protections beyond those available in the federal courts, at least where those protections required the exclusion of relevant evidence. ${ }^{170}$ The desire that prompted Proposition 8 is still very much alive, as evidenced by the 1990 passage of Proposition 115 which, like Proposition 8, urged conformity with federal constitutional dictates as a way to "[restore] balance" to a state criminal justice systein that has "urmecessarily expanded the rights of accused criminals." 171 Proposition 115 went significantly further than Proposition 8, however, by limiting all rights of criminal defendants to those secured by the Umited States Constitution. ${ }^{172}$ The California Supreme Court recently held that this change in constitutional structurc was too far-reaching and fundamental to be accomplished through the initiative process. ${ }^{173}$ Regardless of Proposition 115, it seens unlikely that the corpus delicti rule would survive judicial scrutiny in the wake of Proposition 8, while a corroboration rule of the federal type alinost certainly would.

168. See supra Part I.

169. See supra text accompanying notes $150-60$.

170. See supra notes $145-46$ and accompanying text.

171. Ballot Pamphlet 1990, supra note 58, at 33.

172. The initiative proposed, among other things, the following amendment to article I, section 24 of the California Constitution:

In criminal cases the rights of a defendant to equal protection of the laws, to due process of law, to the assistance of counsel, to be personally present with counsel, to a speedy and public trial, to compel the attendance of witnesses, to confront the witnesses against him or her, to be free from unreasonable searches and seizures, to privacy, to not be compelled to be a witness against himself or herself, to not be placed twice in jeopardy for the same offense, and to not suffer the imposition of cruel or unusual punishinent, shall be construed ... im a manner consistent with the Constitution of the Umited States. This Constitution shall not be construed by the courts to afford greater rights to criminal defendants than those afforded by the Constitution of the United States...."

Id. (emphasis added).

173. Raven v. Deukmejian, 52 Cal. 3d 336, 341, 801 P.2d 1077, 1080, 276 Cal. Rptr. 326, 329 (1990). The court held that the only means of accomplishing the proposed amendment of article I, section 24 of the California Constitution would be either a constitutional convention ratified by popular vote or a legislative proposal subinitted to the electorate for approval. Id. at 349-55, 801 P.2d 1085-89, 276 Cal. Rptr. 334-38. 
There seems little poimt in awaiting a judicial determination, lowever, since both the legislature and the courts have already taken significant steps toward outlining a state policy regarding extrajudicial confession evidence. California courts should admit into evidence the out-of-court confessions and admissions of criminal defendants. Furthermore, they should permit convictions to rest on such statements if, after having considered all the evidence, they believe those statements to be truthful and rehiable. The California Legislature should enact an evidence code provision embracing this rule and eliminating the corpus delicti rule as it now exists in California. 
